\title{
Peran Integritas Personal sebagai Pemediasi pada Pengaruh Lingkungan Etika Organisasi, Kualitas Pengendalian Internal dan Keadilan Organisasi terhadap Terjadinya Fraud
}

\author{
Gustanty Dian Fitria ${ }^{1}$, Amilin ${ }^{2}$ \\ ${ }^{1}$ Universitas Pancasila, Jl. Srengseng Sawah, Jagakarsa, Jakarta Selatan 12640 \\ ${ }^{2}$ Universitas Islam Negeri Syarif Hidayatullah, Jl. Ir. H. Djuanda No. 95, Ciputat, Tangerang Selatan 15412
}

I N F O A R T I K E L

\section{JEL Classification:}

H83

Keywords:

organizational environmental ethics, organizational justice,

internal quality control.

\section{$A B S T R A C T$}

Fraud phenomenon occurs in many government institutions. Fraudulent practices in government accounting materially detrimental to the country. Therefore these crimes fall into the category of extraordinary crime. There needs to be an attempt to commit the crime prevention. This study aims to determine the environmental impact organizational ethics, justice organization and the quality of internal controls against fraud with personal integrity intervening either partially or simultaneously. Source of data used in this study was a questionnaire distributed to 160 employees of the Center for Agricultural Land Resources Ministry of Agriculture. Analysis of the data used is the analysis of Structural Equation Modeling (SEM). The results show that the organization's environmental ethics, justice organization and the quality of internal control occurrence of fraud by an intervening variable of personal integrity.

\section{$A B S T R A K$}

Fenomena fraud banyak terjadi di institusi pemerintahan. Praktik kecurangan akuntansi di pemerintah merugikan negara secara material. Oleh karenanya kejahatan ini masuk dalam kategori extra ordinary crime. Perlu adanya upaya untuk melakukan pencegahan pada kejahatan ini. Studi ini bertujuan untuk mengetahui pengaruh lingkungan etika organisasi, keadilan organisasi dan kualitas pengendalian internal terhadap terjadinya fraud dengan intervening integritas personal baik secara parsial maupun simultan. Sumber data yang digunakan dalam penelitian ini adalah kuesioner yang disebarkan kepada 160 orang pegawai Balai Besar Sumber Daya Lahan Pertanian Kementerian Pertanian. Analisis data yang digunakan adalah analisis Structural Equation Modelling (SEM). Hasil penelitian menunjukkan bahwa lingkungan etika organisasi, keadilan organisasi dan kualitas pengendalian internal berpengaruh terhadap terjadinya fraud dengan variabel intervening integritas personal.

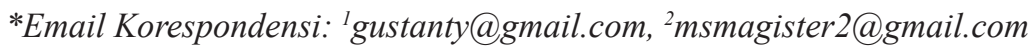




\section{Pendahuluan}

Beberapa riset akuntansi mulai mencoba menghubungkan dan menganggap penting untuk memasukkan aspek keperilakuan dalam akuntansi. Sejak meningkatnya orang yang sudah memberikan pengakuan terhadap beberapa aspek perilaku dari akuntansi terdapat suatu kecenderungan untuk memandang secara lebih luas terhadap bagian akuntansi yang lebih subtansial. Perspektif perilaku menurut pandangan ini telah dipenuhi dengan baik sehingga membuat sistem akuntansi yang lebih dapat dicerna dan lebih bisa diterima oleh para manajer/pimpinan dan karyawannya. Menurut Suartana (2010), salah satu bentuk riset akuntansi keperilakukan adalah pengendalian manajemen dan kecurangan akuntansi (fraud). Tingginya fenomena fraud yang terjadi di instansi pemerintahan saat ini yang berupa korupsi, kolusi dan nepotisme banyak terjadi di segala aspek kehidupan bangsa Indonesia.

Saat ini, KPK menangani kasus tindak pidana korupsi yang melibatkan sedikitnya 17 gubernur (52\%) dan 158 bupati/walikota (30\%), dan baru saja, kembali ditemui kasus dugaan suap penentuan kuota untuk impor daging sapi oleh importir, yang diduga adanya keterlibatan dari pejabat di partai politik dan indikasi keterlibatan pihak Kementerian Pertanian, sebagaimana diungkap KPK yang menyebutkan bahwa Pihak Kementerian Pertanian menjadi salah satu pijakan KPK dalam menyidik kasus dugaan suap impor daging ini, mengingat kasus ini memang berkaitan dengan Kementerian Pertanian. Pasalnya, saat ini yang sedang ditangani adalah dugaan suapnya dan itu dikaitkan ke Kementerian Pertanian (Pratama, 2013).

Kecurangan dan kinerja yang menurun dari pegawai dapat terjadi dikarenakan adanya motivasi di dalam diri mereka. Pada saat karyawan menganggap keadilan di dalam organisasi yang kurang sesuai dan adanya perangsang serta peluang untuk melakukan kecurangan, maka rasionalisasi membenarkan perilaku curang tersebut. Untuk mencegah terjadinyahal tersebut, dimulai daripengendalian internal (Puspitadewi dan Irwandi, 2012).

Kecurangan akuntansi sangat erat hubungannya dengan etika. Kecurangan akuntansi merupakan suatu tindakan ilegal. Menurut Baucus (1994) dalam Hernandez dan Groot (2007), secara umum perilaku ilegal adalah bagian dari perilaku tidak etis, oleh karena itu ada hukum yang harus ditegakkan sebagai bagian dari usaha penegakkan standar moral. Hasil penelitian Wilopo (2006) menemukan bahwa semakin tinggi level penalaran moral individu akan semakin cenderung tidak berbuat kecurangan akuntansi.

Praktik kecurangan akuntansi di pemerintahan sangat merugikan negara, oleh karena itu perlu diadakan upaya pencegahan. Pencegahan praktik Kecurangan Akuntansi. Wilopo (2006) dalam penelitiannya mengemukakan bahwa upaya menghilangkan perilaku tidak etis manajemen dan kecenderungan kecurangan akuntansi dapat dilakukan antara lain dengan: Mengefektifkan pengendalian internal, termasuk penegakan hukum; Perbaikan sistem pengawasan dan pengendalian; Pelaksanaan good governance dan memperbaiki moral dari pengelola perusahaan, yang diwujudkan dengan mengembangkan sikap komitmen terhadap perusahaan, negara dan masyarakat.

Wells (2007), mendefinisikan fraud sebagai segala macam bentuk kriminal dengan menggunakan tipu muslihat sebagai dasar modus operandinya. Singleton dan Singleton (2010) mendefinisikan: "Fraud as a crime". Fraud is a generic term, and embraces all the multifarious means which human ingenuity can devise, which are resorted to by one individual, to get an advantage over another by false representations".

Personal integrity mengacu kepada kode etik personal yang dimiliki individu. Personal integrity dapat diobservasi lewat teori perkembangan moral seperti dalam penelitianpenelitian etika (Puspasari dan Suwardi, 2012).

Amrizal (2007) menjelaskan bahwa setiap organisasi bertanggung jawab untuk 
berusaha mengembangkan suatu perilaku organisasi yang mencerminkan kejujuran dan etika yang dikomunikasikan secara tertulis dan dapat dijadikan pegangan oleh seluruh pegawai. Kultur tersebut harus memiliki akar dan memiliki nilai-nilai luhur yang menjadi dasar bagi etika pengelolaan suatu organisasi atau suatu entitas.

\section{Menurut COSO (Commite Of}

Sponsoring Organization) (Hall, 2001) mendefinisikan pengendalian internal sebagai proses yang diimplementasikan oleh dewan direksi, manajemen, serta seluruh staff dan karyawan di bawah arahan mereka dengan tujuan untuk memberi jaminan yang memadai atas tercapainya tujuan pengendalian.

Menurut Robbins dan Judge (2009), keadilan organisasi adalah persepsi keseluruhan mengenai apa yang dianggap adil di tempat kerja. Pegawai menganggap organisasinya berlaku adil saat mereka meyakini bahwa hasil yang mereka terima dan tata cara hasil tersebut diterima adalah adil.

Beberapa masalah yang diidentifikasi dalam penelitian ini antara lain: (1) Headline berita saat ini menyebutkan bahwa terdapat indikasi keterlibatan Kementerian Pertanian dalam kasus impor sapi yang merupakan bentuk fraud. (2) Hasil audit investigasi sejak tahun 2007 sampai dengan Desember 2012 menginformasikan bahwa terdapat pegawai sebanyak 278 orang yang terkena sanksi atas tindakan fraud yang dilakukan oleh pegawai yang bersangkutan. (3) Menurunnya tingkat integritas pegawai pada perusahaan atau instansi tertentu membuat celah munculnya fraud. (4) Ketidakadilan organisasi dalam memberikan kepuasan kerja pada pegawainya. (5) Lingkungan etika yang mendukung terjadinya fraud menyebabkan seseorang terbiasa melakukan kecurangan.

Penelitian ini bertujuan untuk mengetahui pengaruh Lingkungan Etika Organisasi, Keadilan Organisasi dan Kualitas Pengendalian Internal terhadap terjadinya Fraud dengan dimoderasi oleh Integritas Personal baik secara parsial maupun simultan

\section{Telaah Teori dan Pengembangan Hipotesis}

Fraud atau kecurangan dapat didefinisikan sebagai tindakan kriminal (crime) yang dilakukan secara sengaja oleh seseorang atau beberapa orang berupa kecurangan/ ketikakberesan (irregularities) atau penipuan yang melanggar hukum (illegal act) untuk mendapatkan keuntungan atau mengakibatkan kerugian suatu organisasi (perusahaan).

Faktor-faktor pemicu kecurangan yang saat ini dikenal dengan "Fraud Triangle" (Singleton dan Singleton, 2010), terdiri dari Pressure adalah dorongan yang menyebabkan seseorang melakukan fraud; Opportunity adalah peluang yang memungkinkan fraud terjadi; Rasionalisasi menjadi elemen penting dalam terjadinya fraud, dimana pelaku mencari pembenaran atas tindakannya.

Personal integrity mengacu kepada kode etik personal yang dimiliki individu. Personal integrity dapat diobservasi lewat teori perkembangan moral seperti dalam penelitianpenelitian etika (Puspasari dan Suwardi, 2012). Menurut Moroney (2008), integritas personal diukur dengan tingkat kejujuran, keberanian, sikap bijaksana, dan tanggung jawab

Amrizal (2007) menjelaskan bahwa setiap organisasi bertanggung jawab untuk berusaha mengembangkan suatu perilaku organisasi yang mencerminkan kejujuran dan etika yang dikomunikasikan secara tertulis dan dapat dijadikan pegangan oleh seluruh pegawai. Menurut Amrizal (2007), variabel lingkungan etika organisasi diukur melalui dimensi perilaku etis dan budaya organisasi.

Menurut Mulyadi (2001) pengendalian internal adalah sistem pengendalian internal yang meliputi struktur organisasi, metode dan ukuran-ukuran yang di koordinasikan untuk menjaga kekayaan organisasi, mengecek ketelitian dan keandalan data akuntansi. Menurut Hall (2001) berdasarkan COSO (commite of sponsoring organization), komponen dalam sistem pengendalian terdiri dari lima aktivitas, yang terdiri dari yang terdiri dari Lingkungan 
pengendalian, aktivitas pengendalian, pengawasan kinerja, dan informasi dan komunikasi.

Menurut Robbins dan Judge (2009), keadilan organisasi adalah persepsi keseluruhan mengenai apa yang dianggap adil di tempat kerja. Deustch (1985) dan Tornblom (1992) mendefinisikan keadilan organisasi menjadi 3 tipe, yaitu keadilan distributif, keadilan procedural dan keadilan interaksional (Robbins dan Judge, 2009).

\section{Metode penelitian}

Penelitian ini dilakukan di Balai Besar Sumber Daya Lahan Pertanian Kementerian Pertanian yang beralamat di Jl. Tentara Pelajar Cimanggu Bogor. Penelitian ini dilakukan mulai bulan Februari sampai dengan April 2013.

Metode pengumpulan data pada penelitian ini menggunakan kuesioner yang diberikan kepada 160 orang pegawai di lingkungan Balai Besar Sumberdaya Lahan Pertanian Kementerian Pertanian. Metode analisis data dengan menggunakan Structural Equation Modeling (SEM) dengan Lisrel 8.7.

Berdasarkan kajian teori, maka dapat dibuat diagram alur hubungan antar variabel beserta dimensinya. Hubungan tersebut dapat dilihat pada Gambar 1.
Persamaan struktural dari model diagram alur pada gambar 1 dapat dinyatakan sebagai berikut:

I.Person $=$

$\beta 1 \mathrm{LEO}+\beta 2 \mathrm{KPI}+\beta 3 \mathrm{~K} . \mathrm{Org}+\mathrm{e} 1 \mathrm{Fraud}=\beta 1$

I.Person $+\beta 2 \mathrm{LEO}+\beta 3 \mathrm{KPI}+\beta 4$ K.Org $+\mathrm{e} 2$

Keterangan:

I.Person: Integritas Personal

LEO : Lingkungan Etika Organisasi

KPI : Kualitas Pengendalian Internal

K.Org : Keadilan Organisasi

\section{Hasil penelitian dan Pembahasan}

Dalam penelitian ini, data diperoleh melalui kuesioner yang diberikan kepada pegawai lingkup Balai Besar Sumber Daya Lahan Pertanian Kementerian Pertanian. Kuesioner yang disebarkan kepada responden sebanyak 160 orang, tetapi kuesioner yang dikembalikan hanya 135 . Jadi jumlah data yang dianalisis sebanyak 135. Pengumpulan data dalam penelitian ini dilakukan selama kurang lebih 2 minggu terhitung bulan Maret sampai awal April 2013.

Karakteristik responden terdiri dari jenis kelamin, usia, pendidikan terakhir, dan lama bekerja.

\section{Gambar 1. Diagram Path}

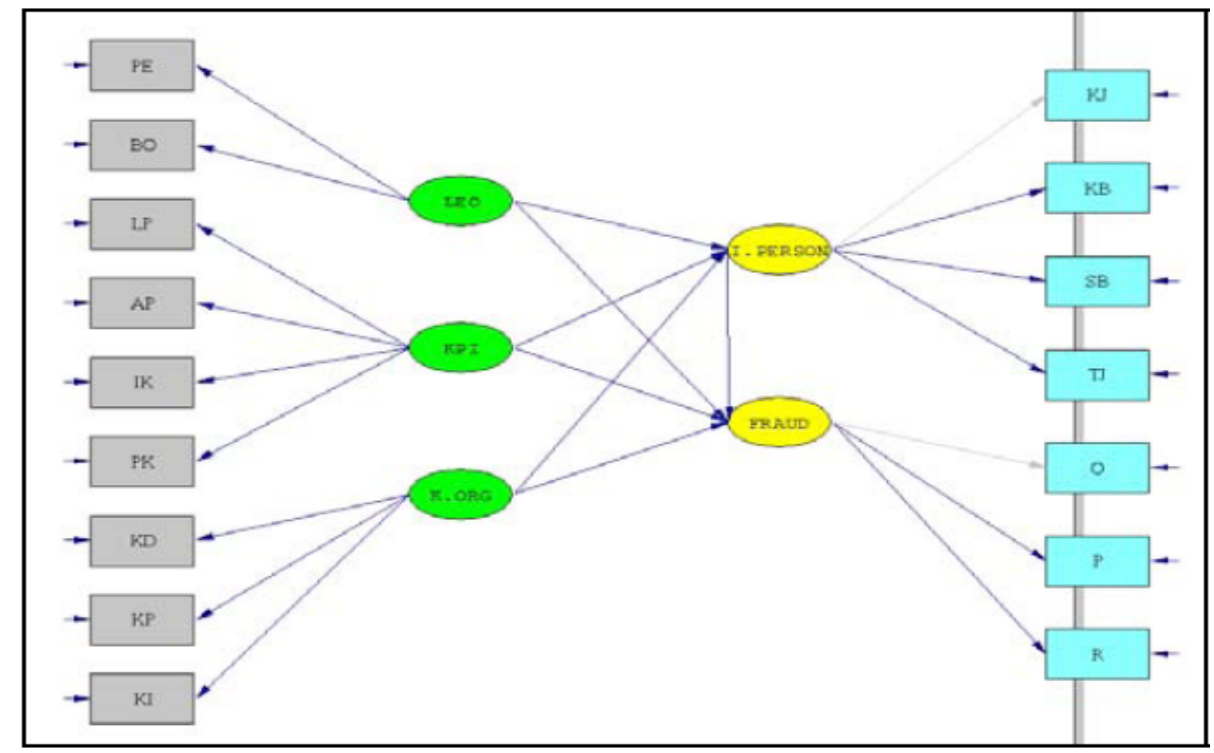


Data tersebut terkumpul dari hasil survey terhadap 135 responden yang merupakan pegawai lingkup Balai Besar Sumber Daya Langkah-langkah untuk menganalisis Lahan Pertanian Kementerian Pertanian. Berikut penjabaran karakteristik responden.

\section{Tabel 1. Karakteristik Responden}

\begin{tabular}{llcc}
\hline \multicolumn{2}{c}{ Karakteristik } & Jumlah & Presentase \\
\hline Jenis & Laki - laki & 97 & $72 \%$ \\
Kelamin & Perempuan & 38 & $28 \%$ \\
& Total & $\mathbf{1 3 5}$ & $\mathbf{1 0 0} \%$ \\
Usia & Kurang dari 30 Tahun & 16 & $12 \%$ \\
& 31-40 Tahun & 30 & $22 \%$ \\
Pendidikan & SMU/Sederajat & 22 & $16 \%$ \\
Terakhir & Diploma & 33 & $24 \%$ \\
& Lebih dari 50 & 55 & $41 \%$ \\
& S1 & $\mathbf{1 3 5}$ & $\mathbf{1 0 0} \%$ \\
& S2 dan S3 & 17 & $47 \%$ \\
& Total & 135 & $\mathbf{1 0 0} \%$
\end{tabular}

\begin{tabular}{llcc} 
Lama & $0-3$ Tahun & $\mathbf{1 4}$ & $\mathbf{1 0 \%}$ \\
Bekerja & 3.1 - 6 Tahun & $\mathbf{8}$ & $\mathbf{6 \%}$ \\
& 6.1 - 10 Tahun & $\mathbf{1 2}$ & $\mathbf{9 \%}$ \\
& Lebih dari 10 Tahun & $\mathbf{1 0 1}$ & $\mathbf{7 5 \%}$ \\
& Total & $\mathbf{1 3 5}$ & $\mathbf{1 0 0} \%$ \\
\hline
\end{tabular}

Langkah - langkah untuk menganalisis SEM dalam penelitian ini dimulai dengan membuat sebuah model yang dikembangkan dari teori-teori yang berhubungan dalam penelitian. Kemudian dibuatkan diagram alur (path diagram) yang menunjukkan hubungan antara variabel independen dengan variabel dependen. Diagram alur dikonversi ke dalam serangkaian persamaan struktural model yang dikembangkan.

Analisis goodness of fit overall model digunakan untuk menguji kecocokan antar variable secara bersama-sama dalam suatu model yang dibuat.

\section{Gambar 2. Estimasi Overall Model}

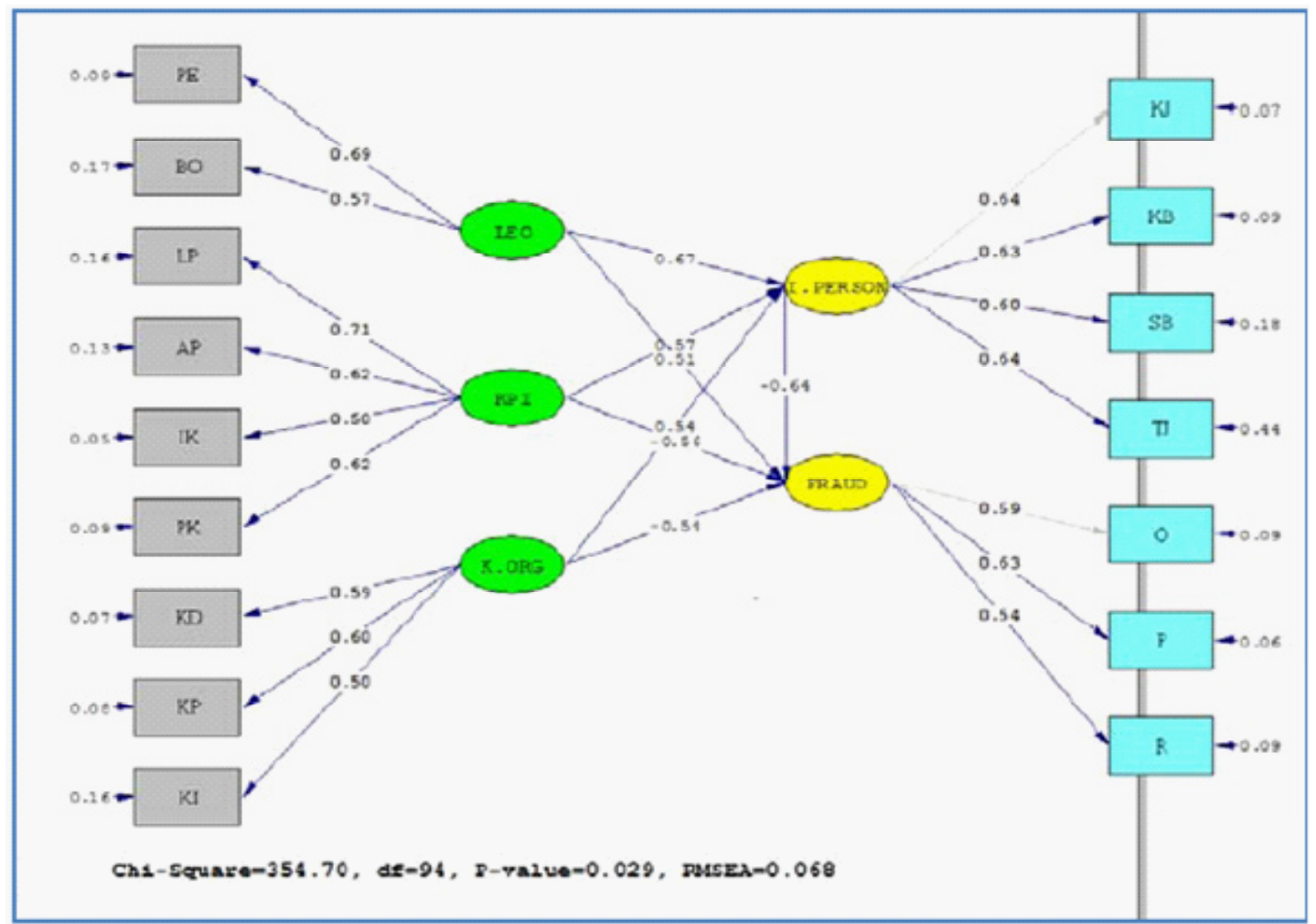


Hasil uji overall model fit akan ditunjukan dalam tabel 2 berikut ini:
Structural Modeling. Weights Analysis

Structural Modeling. Pengujian

Tabel 2.

Kriteria Goodness of Fit overall Model

\begin{tabular}{cccc}
\hline Goodness of-fit index & Cut of value & hasil & Kesimpulan \\
\hline Significance Probability & $\geq 0,05$ atau $\geq 0,01$ & 0.03 & Good fit \\
RMSEA & $\leq 0,08$ & 0.07 & Good fit \\
GFI & $\geq 0,90$ & 0.94 & Good fit \\
AGFI & $\geq 0,90$ & 0.92 & Good fit \\
CFI & $\geq 0,95$ & 0.90 & Marginal fit \\
IFI & $\geq 0,95$ & 0.95 & Good fit \\
RFI & $\geq 0,90$ & 0.89 & Marginal fit \\
NFI & $\geq 0,95$ & 0.96 & Good fit \\
\hline
\end{tabular}

Dari tabel 2 dapat dilihat bahwa hampir semua ukuran kriteria goodness of fit menunjukkan kecocokan yang baik, sehingga dapat disimpulkan bahwa kecocokan keseluruhan model adalah good fit. Berdasarkan uji kecocokan yang dilakukan di atas, maka model penelitian yang dibuat dapat diterima dengan baik, sehingga analisis data berikutnya untuk mengetahui hubungan antar variabel dapat dilakukan.

Tahap pengujian hipotesis ini adalah untuk menguji hipotesis penelitian yang diajukan pada Bab III. Pengujian hipotesis ini didasarkan atas pengolahan data penelitian dengan menggunakan analisis SEM, yaitu dengan cara menganalisis nilai regresi yang ditampilkan pada Regression Weights Analysis hipotesis ini adalah dengan menganalisa nilai Critical Ratio (CR) dan nilai Probability (P). Nilai CR (merupakan nilai t hitung) dan $P$ ini dibandingkan dengan batasan statistik yang disyaratkan, yaitu untuk hipotesis yang berpengaruh positif, hipotesis penelitian dapat diterima jika thitung $\geq$ ttabel dan untuk hipotesis yang berpengaruh negatif, hipotesis penelitian dapat diterima jika thitung $<-$ ttabel. Karena jumlah responden pada penelitian ini adalah 135 orang, maka nilai thitung $=1,66$, dengan nilai tingkat signifikansi $\mathrm{P} \leq 0,05$.

Pengujian hipotesis dalam penelitian ini yaitu membandingkan nilai thitung dengan ttabel, Jika thitung $>$ ttabel, atau thitung $<$-ttabel maka hipotesis diterima. Berikut menggambarkan hasil pengujian hipotesis.

Tabel 3. Hasil Pengujian Hipotesis

\begin{tabular}{llccccc}
\hline No. & \multicolumn{1}{c}{ Variabel } & $\begin{array}{c}\text { CR } \\
\text { (thitung) }\end{array}$ & ttabel & Sig & $\begin{array}{c}\text { Estimasi } \\
\text { Regresi }\end{array}$ & Kesimpulan \\
\hline 1 & X1 terhadap Y & 13.67 & & 0,049 & 0,67 & Ha1 diterima \\
2 & X2 terhadap Y & 13,90 & 1.66 & 0,041 & 0,57 & Ha2 diterima \\
3 & X3 terhadap Y & 12,14 & & 0,03 & 0,54 & Ha3 diterima \\
4 & X1 terhadap Y & 12,14 & & 0,042 & 0,51 & Ha4 diterima \\
5 & X2 terhadap Z & $-14,00$ & & 0,04 & 0,56 & Ha5 diterima \\
6 & X3 terhadap Z & $-11,02$ & 1.66 & 0,049 & 0,54 & Ha6 diterima \\
7 & Y terhadap Z & $-18,29$ & & 0,035 & 0,64 & Ha7 diterima \\
\hline No. & $\quad$ Variabel & & $\mathbf{R 2}$ & Besarnya Pengaruh & Kesimpulan \\
\hline 8 & X1,X2,X3 terhadap Y & 0.621 & 0.621 & & $62.1 \%$ & Ha8 diterima \\
9 & X1,X2,X3 terhadap Z & 0.841 & $84.1 \%$ & & $84.1 \%$ & Ha9 diterima \\
\hline
\end{tabular}


Apabila hasil olah data menunjukkan nilai yang memenuhi syarat tersebut, maka hipotesis penelitian yang diajukan dapat diterima. Secara rinci pengujian hipotesis penelitian akan dibahas secara bertahap sesuai dengan hipotesis yang telah diajukan. Pada penelitian ini diajukan duabelas hipotesis yang selanjutnya pembahasannya dilakukan di bagian berikut. Pembahasan Hipotesis dalam Persamaan Struktural 1. Persamaan struktural 1, dituliskan sebagai berikut:

\section{IPERSON $=0.67 * \mathrm{LEO}+0.57 * \mathrm{KPI}+0.54^{*} \mathrm{KORG}$, Erovvar. $=0.94, \mathrm{R}^{2}=0.621$ $\begin{array}{lll}(0.049) & (0.041) \quad(0.03) \quad(0.18)\end{array}$ $\begin{array}{llll}13.67 & 13.90 & 12.14 & 5.13\end{array}$}

Pada persamaan struktural 1, hipotesis yang akan diuji adalah hipotesis 1 , hipotesis 2, Pada persamaan hipotesis 3 , dan hipotesis 8 .

Berdasarkan persamaan di atas, dapat ditunjukkan bahwa variabel Lingkungan Etika Organisasi, Kualitas Pengendalian Internal, dan Keadilan Organisasi memiliki pengaruh secara simultan terhadap Integritas Personal dengan nilai $\mathrm{R}^{2}$ sebesar 0,621 . Artinya, besarnya pengaruh Lingkungan Etika Organisasi, Kualitas Pengendalian Internal, dan Keadilan Organisasi secara simultan terhadap Integritas Personal adalah sebesar 62,10\%. Dari pembuktian tersebut dapat disimpulkan bahwa hipotesis delapan (Ha8) yang menyatakan Lingkungan Etika Organisasi, Kualitas Pengendalian Internal, dan Keadilan Organisasi secara simultan berpengaruh terhadap Integritas Personal dapat diterima.

Persamaan di atas menunjukkan bahwa nilai t untuk variabel Lingkungan Etika Organisasi adalah sebesar 13,67, artinya thitung lebih besar dari ttabel $(13,67>1,66)$ padatingkat signifikansi 0,049 yang berada dibawah 0,05. Hal ini menunjukkan bahwa Lingkungan Etika Organisasi berpengaruh positif dan signifikan terhadap Integritas Personal. Nilai estimasi regresi adalah sebesar 0,63 , hal ini menunjukan bahwa jika terjadi peningkatan sebesar 1 satuan pada Lingkungan Etika Organisasi akan menghasilkan peningkatan sebesar 0,67 satuan pada Integritas Personal. Dari pembuktian tersebut dapat disimpulkan bahwa hipotesis pertama (Ha1) yang menyatakan bahwa Lingkungan Etika Organisasi berpengaruh terhadap Integritas Personal dapat diterima.

Nilai $\mathrm{t}$ untuk variabel Kualitas Pengendalian Internal adalah sebesar 13,90, artinya thitung lebih besar dari ttabel $(13,90$ $>1,66)$ pada tingkat signifikansi 0,041 yang berada dibawah 0,05. Hal ini menunjukkan bahwa Kualitas Pengendalian Internal berpengaruh positif dan signifikan terhadap Integritas Personal. Nilai estimasi regresi adalah sebesar 0,57, hal ini menunjukkan bahwa jika terjadi peningkatan sebesar 1 satuan pada Kualitas Pengendalian Internal akan menghasilkan peningkatan sebesar 0,57 satuan pada Integritas Personal. Dari pembuktian tersebut dapat disimpulkan bahwa hipotesis kedua (Ha2) yang menyatakan bahwa Kualitas Pengendalian Internal berpengaruh terhadap Integritas Personal dapat diterima.

Persamaan di atas menunjukkan bahwa nilai $\mathrm{t}$ untuk variabel Keadilan Organisasi adalah sebesar 12,14, artinya thitung lebih besar dari ttabel $(12,14>1,66)$ pada tingkat signifikansi 0,03 yang berada di bawah 0,05 . Hal ini menunjukkan bahwa Keadilan Organisasi berpengaruh positif dan signifikan terhadap Integritas Personal. Nilai estimasi regresi adalah sebesar 0,54, hal ini menunjukkan bahwa jika terjadi peningkatan sebesar 1 satuan pada Keadilan Organisasi akan menghasilkan peningkatan sebesar 0,54 satuan pada Integritas Personal. Dari pembuktian tersebut dapat disimpulkan bahwa hipotesis ketiga (Ha3) yang menyatakan bahwa Keadilan Organisasi berpengaruh terhadap Integritas Personal dapat diterima. Pembahasan Hipotesis pada Persamaan Struktural 2. Persamaan struktural 2, dituliskan sebagai berikut:

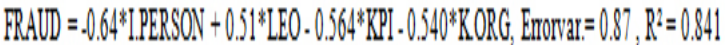 $\begin{array}{lllll}(0.035) & (0.042) & (0.04) & (0.049) & (0.15) \\ .18 .29 & 12.14 & .14 .00 & .11 .026 .52 & \end{array}$}

Pada persamaan struktural2, hipotesis yang akan 
diuji adalah hipotesis 4 , hipotesis 5 , hipotesis 6, hipotesis 7, dan hipotesis 9. Berdasarkan persamaan di atas, dapat ditunjukkan bahwa variabel Integritas Personal, Lingkungan Etika Organisasi, Kualitas Pengendalian Internal, dan Keadilan Organisasi memiliki pengaruh secara simultan terhadap potensi terjadinya Fraud dengan nilai $\mathrm{R} 2$ sebesar 0,841 . Artinya, besarnya pengaruh Integritas Personal, Lingkungan Etika Organisasi, Kualitas Pengendalian Internal, dan Keadilan Organisasi secara simultan terhadap Fraud adalah sebesar 84,1\%. Dari pembuktian tersebut dapat disimpulkan bahwa hipotesis sembilan (Ha9) yang menyatakan bahwa Lingkungan Etika Organisasi, Kualitas Pengendalian Internal, Keadilan Organisasi dan Integritas Personal secara simultan berpengaruh terhadap potensi terjadinya fraud dapat diterima.

Nilai t untuk variabel Lingkungan Etika Organisasi adalah sebesar 12,14, artinya thitung lebih besar dari ttabel $(12,14>-1,66)$ pada tingkat signifikansi 0,042 yang berada dibawah 0,05. Hal ini menunjukkan bahwa Lingkungan Etika Organisasi berpengaruh positif dan signifikan terhadap potensi terjadinya Fraud. Nilai estimasi regresi adalah sebesar 0,51 , hal ini menunjukkan bahwa jika terjadi peningkatan sebesar 1 satuan pada Lingkungan Etika Organisasi akan menghasilkan peningkatan sebesar 0,51 satuan pada potensi terjadinya Fraud. Dari pembuktian tersebut dapat disimpulkan bahwa hipotesis keempat (Ha4) yang menyatakan bahwa Lingkungan Etika Organisasi berpengaruh terhadap potensi terjadinya Fraud dapat diterima.

Nilai $\mathrm{t}$ untuk variabel Kualitas Pengendalian Internal adalah sebesar $-14,00$, artinya thitung lebih kecil dari ttabel $(-14,00$ $<-1,66)$ pada tingkat signifikansi 0,04 yang berada dibawah 0,05 . Hal ini menunjukkan bahwa Kualitas Pengendalian Internal berpengaruh negatif dan 10 signifikan terhadap potensi terjadinya Fraud. Nilai estimasi regresi adalah sebesar -0,56, hal ini menunjukkan bahwa jika terjadi peningkatan sebesar 1 satuan pada Kualitas Pengendalian Internal akan menghasilkan penurunan sebesar 0,56 satuan pada potensi terjadinya Fraud. Dari pembuktian tersebut dapat disimpulkan bahwa hipotesis kelima (Ha5) yang menyatakan bahwa Kualitas Pengendalian Internal berpengaruh terhadap potensi terjadinya Fraud dapat diterima.

Nilai $t$ untuk variabel Keadilan Organisasi adalah sebesar -11,02, artinya thitung lebih kecil dari ttabel $(-11,02<-1,66)$ pada tingkat signifikansi 0,049 yang berada dibawah 0,05. Hal ini menunjukkan bahwa Keadilan Organisasi berpengaruh negatif dan signifikan terhadap potensi terjadinya Fraud. Nilai estimasi regresi adalah sebesar $-0,54$, hal ini menunjukkan bahwa jika terjadi peningkatan sebesar 1 satuan pada Keadilan Organisasi akan menghasilkan penurunan sebesar 0,54 satuan pada potensi terjadinya Fraud. Dari pembuktian tersebut dapat disimpulkan bahwa hipotesis enam (Ha6) yang menyatakan bahwa Keadilan Organisasi berpengaruh terhadap potensi terjadinya Fraud dapat diterima.

Dari persamaan di atas, ditunjukkan bahwa nilai t untuk variabel Integritas Personal adalah sebesar $-18,29$, artinya thitung lebih kecil dari ttabel $(-18,29<-1,66)$ pada tingkat signifikansi 0,035 yang berada dibawah 0,05. Hal ini menunjukkan bahwa Integritas Personal berpengaruh negatif dan signifikan terhadap potensi terjadinya Fraud. Nilai estimasi regresi adalah sebesar $-0,64$, hal ini menunjukkan bahwa jika terjadi peningkatan sebesar 1 satuan pada Integritas Personal akan menghasilkan penurunan sebesar 0,64 satuan pada potensi terjadinya Fraud. Dari pembuktian tersebut dapat disimpulkan bahwa hipotesis tujuh (Ha7) yang menyatakan bahwa Integritas Personal berpengaruh terhadap potensi terjadinya Fraud dapat diterima.

Berdasarkan persamaan struktural yang sudah didapat, maka dapat dituliskan koefisien jalur pada persamaan struktural yang dibuat pada analisis jalur, sebagai berikut:

1. Koefisien jalur/estimasi regresi X1 terhadap Y adalah 0,67

2. Koefisien jalur/estimasi regresi X2 terhadap 
Y adalah 0,57

3. Koefisien jalur/estimasi regresi $\mathrm{X} 3$ terhadap $\mathrm{Y}$ adalah 0,54

4. Koefisien jalur/estimasi regresi X1 terhadap $\mathrm{Z}$ adalah 0,51

5. Koefisien jalur/estimasi regresi X2 terhadap $\mathrm{Z}$ adalah $-0,56$

6. Koefisien jalur/estimasi regresi X3 terhadap $\mathrm{Z}$ adalah $-0,54$

7. Koefisien jalur/estimasi regresi $Y$ terhadap $Z$ adalah $-0,64$

Untuk lebih jelasnya, tabel berikut merangkum seluruh hasil koefisien jalur serta pengaruh tidak langsung dan pengaruh total. sebagai Intervening dapat diterima.

Nilai koefisien jalur pengaruh Kualitas PengendalianInternalterhadappotensiterjadinya Fraud (pengaruh langsung) adalah sebesar -0,56 dan pengaruh Kualitas Pengendalian Internal terhadap potensi terjadinya Fraud melalui Intervening Integritas Personal (pengaruh tidak langsung) adalah sebesar -0,36. Hal tersebut menunjukkan bahwa variabel Kualitas Pengendalian Internal lebih besar berpengaruh menurunkan potensi terjadinya Fraud tanpa melalui Integritas Personal. Sehingga hipotesis kesebelas (Ha11) yang menyatakan bahwa Kualitas Pengendalian Internal berpengaruh

Tabel 4.

Hasil Koefisien Jalur dan Pengaruh Variabel Penelitian

\begin{tabular}{|c|c|c|c|c|}
\hline \multirow[t]{2}{*}{ Variabel } & \multirow[t]{2}{*}{ Koefisien jalur } & \multicolumn{2}{|c|}{ Pengaruh } & \multirow[t]{2}{*}{ Total } \\
\hline & & Langsung & Tidak Langsung & \\
\hline $\mathrm{X} 1 \rightarrow \mathrm{Y}$ & 0,67 & 0,67 & - & 0,67 \\
\hline $\mathrm{X} 2 \rightarrow \mathrm{Y}$ & 0,57 & 0,57 & - & 0,57 \\
\hline $\mathrm{X} 3 \rightarrow \mathrm{Y}$ & 0,54 & 0,54 & - & 0,54 \\
\hline $\mathrm{X} 1 \rightarrow \mathrm{Z}$ & 0,51 & 0,51 & - & 0,51 \\
\hline $\mathrm{X} 2 \rightarrow \mathrm{Z}$ & $-0,56$ & $-0,56$ & - & $-0,56$ \\
\hline $\mathrm{X} 3 \rightarrow \mathrm{Z}$ & $-0,54$ & $-0,54$ & - & $-0,54$ \\
\hline $\mathrm{Y} \rightarrow \mathrm{Z}$ & $-0,64$ & $-0,64$ & - & $-0,64$ \\
\hline $\mathrm{X} 1 \rightarrow \mathrm{Y} \rightarrow \mathrm{Z}$ & $(0,67 \times-0,64)$ & 0,51 & $-0,43$ & 0,08 \\
\hline $\mathrm{X} 2 \rightarrow \mathrm{Y} \rightarrow \mathrm{Z}$ & $(0,57 \times-0,64)$ & $-0,56$ & $-0,36$ & $-0,92$ \\
\hline $\mathrm{X} 3 \rightarrow \mathrm{Y} \rightarrow \mathrm{Z}$ & $(0,54 \times-0,64)$ & $-0,54$ & $-0,35$ & $-0,89$ \\
\hline
\end{tabular}

Berdasarkan tabel di atas diketahui bahwa nilai koefisien jalur pengaruh Lingkungan Etika Organisasi terhadap potensi terjadinya Fraud (pengaruh langsung) sebesar 0,51 dan nilai koefisien jalur pengaruh Lingkungan Etika Organisasi terhadap potensi terjadinya Fraud melalui intervening Integritas Pegawai (pengaruh tidak langsung) adalah sebesar $-0,43$. Maka dapat disimpulkan bahwa Lingkungan Etika Organisasi berpengaruh negatif terhadap potensi terjadinya Fraud melalui Integritas Personal. Sehingga hipotesis kesepuluh (Ha10) yang menyatakan bahwa Lingkungan Etika Organisasi berpengaruh terhadap potensi terjadinya Fraud melaui Integritas Personal terhadap potensi terjadinya Fraud/Kecurangan akuntansi melalui Integritas Personal sebagai intervening dapat diterima.

Nilai koefisien jalur pengaruh Keadilan Organisasi terhadap potensi terjadinya Fraud (pengaruh langsung) adalah sebesar $-0,54$ dan pengaruh Keadilan Organisasi terhadap potensi terjadinya Fraud melalui Intervening Integritas Personal (pengaruh tidak langsung) adalah sebesar -0,35. Hal tersebut menunjukkan bahwa variabel Keadilan Organisasi lebih besar berpengaruh menurunkan potensi terjadinya Fraud tanpa melalui Integritas Personal. Sehingga hipotesis keduabelas (Ha12) yang menyatakan bahwa Keadilan Organisasi 
berpengaruh terhadap potensi terjadinya Fraud/Kecurangan akuntansi melalui Integritas Personal sebagai intervening dapat diterima.

Berdasarkan tabel di atas dapat dilihat bahwa variabel yang paling berpengaruh terhadap penurunan potensi terjadinya Fraud adalah Integritas Personal dengan nilai koefisien jalur $-0,64$, sedangkan Integritas Personal paling besar dipengaruhi oleh variabel Lingkungan Etika Organisasi dengan nilai koefisien jalur sebesar 0,54. Besarnya pengaruh variabel interaksi tersebut menunjukkan bahwa ada saling ketergantungan antara potensi terjadinya Fraud dengan Integritas Personal. Lingkungan Etika dengan Integritas Personal yang tinggi akan sangat berperan dalam menurunkan potensi terjadinya Fraud. Sedangkan Kualitas Pengendalian Internal dan Keadilan Organisasi secara langsung berpengaruh terhadap penurunan potensi terjadinya Fraud. Hal tersebut mendukung penelitian yang dilakukan oleh Wilopo (2006) yang menghasilkan bahwa Fraud dipengaruhi oleh moral individu, semakin tinggi level penalaran moral individu akan semakin cenderung tidak berbuat Fraud, serta penelitian yang dilakukan oleh Rae dan Subramaniam (2008) yang menyebutkan bahwa faktor yang menyebabkan terjadinya fraud adalah kualitas pengendalian internal dan keadilan organisasi, namun kurang mendukung penelitian yang dilakukan oleh Novita Puspasari dan Eko Suwardi (2012) yang menghasilkan bahwa dalam kondisi terdapat elemen pengendalian internal, individu yang memiliki level penalaran moral rendah cenderung tidak melakukan kecurangan akuntansi.

Organisasi Balai Besar Sumberdaya Lahan Pertanian Kementerian Pertanian bertanggung jawab untuk berusaha mengembangkan suatu perilaku organisasi yang mencerminkan kejujuran dan etika yang dikomunikasikan secara tertulis dan dapat dijadikan pegangan oleh seluruh pegawai. Kultur tersebut harus memiliki nilai-nilai luhur yang menjadi dasar bagi etika pengelolaan suatu organisasi. Pencegahan Fraud di lingkungan organisasi Balai Besar Sumber
Daya Lahan Pertanian dapat dilakukan antara lain melalui penegakkan integritas personal pegawai, peningkatan kualitas pengendalian internal dan penerapan keadilan organisasi bagi seluruh pegawai. Dengan integritas personal pegawai yang tinggi akan menciptakan suatu lingkungan etika organisasi yang berperan dalam menurunkan potensi terjadinya fraud di Kementerian Pertanian.

\section{Simpulan, Keterbatasan dan Implikasi Hasil Penelitian}

Kesimpulan dalam penelitian ini menyatakan bahwa Lingkungan Etika Organisasi, Keadilan Organisasi dan Kualitas Pengendalian Internal memiliki pengaruh positif terhadap Integritas Personal. Lingkungan Etika Organisasi dan keadilan organisasi memiliki pengaruh positif terhadap potensi terjadinya Fraud, sedangkan Kualitas Pengendalian Internal berpengaruh negative terhadap potensi terjadinya Fraud/Kecurangan akuntansi. Penelitian ini juga menemukan bahwa terdapat pengaruh negatif dan signifikan antara Lingkungan Etika organisasi terhadap potensi terjadinya Fraud melalui Integritas Personal sebagai Intervening. Kemudian variable keadilan organisasi dan kualitas pengendalian internal berpengaruh positif terhadap potensi terjadinya Fraud melalui Integritas Personal sebagai intervening.

Saran dalam penelitian ini ditujukan kepada Kepada Pimpinan Balai Besar Sumberdaya Lahan Pertanian Kementerian Pertanian sebaiknya menciptakan budaya organisasi yang baik sehingga lingkungan etika organisasi dapat tercipta dengan baik dan kondusif, berupaya meningkatkan integritas personal pegawai antara lain melalui penerapan dimensi integritas personal yang meliputi budaya jujur, berani, sikap bijaksana dan bertanggung jawab terhadap visi misi organisasi. Selain itu diharapkan meningkatkan kualitas pengendalian internal untuk meminimalisir tingkat kesempatan pegawai untuk melakukan fraud dan menerapkan keadilan organisasi 
antara lain melalui pemberian penghargaan atas martabat dan hakhak yang melekat padanya dan pengenaan sanksi atas kesalahan pegawai tersebut. Kemudian, saran bagi penenelitian selanjutnyadiharapkanpadateknikpengumpulan data penelitian selain menggunakan kuesioner, juga melakukan wawancara terhadap jawaban responden untuk menguatkan hasil yang diperoleh dari kuesioner, sehingga kelemahankelemahan yang ditemukan dapat diminimalisir, serta menyempurnakan daftar pernyataan dalam kuesioner secara lengkap agar tidak bermakna bias dan mudah dipahami oleh responden. Selain itu, penelitian selanjutnya juga disarankan untuk lebih fokus pada desain eksperimen yang lebih sempurna agar lebih dapat menggambarkan kondisi yang lebih nyata.

\section{Daftar Pustaka}

Amrizal, 2007. 'Pencegahan dan Pendeteksian Kecurangan Oleh Internal Auditor', www. bpkp.go.id/public/cegah_deteksi.pdf, diakses pada tanggal 6 Februari 2013.

Hall, James A. 2001. Sistem Informasi Akuntansi, Buku 1. Jakarta: Salemba Empat.

Hernandez, Jose R. , Groot, Tom. 2007. How Trust Underpins Auditor Fraud Risk Assessments. ARCA: Amsterdam Research Center in Accounting

Moroney, J. J. dan McDevitt, R. E.. 2008. The Effects of Moral Reasoning on Financial Reporting Decisions in a Post SarbanesOxley Environment. Behavioral Research of Accounting

Pratama, Fajar. 2013. KPK Cecar Mantan Dirjen Peternakan Soal Penetapan Kuota Impor Sapi. Tersedia: http://news.detik. com/read/2013/03/22/210614/2201646/10/ kpk-cecarmantan- dirjen-peternakan-soalpenetapan-kuota-impor-sapi?9911012. Diakses: 23 maret 2013, Pukul: 10.00 WIB Puspadewi, Paramita., Irwandi, Soni Agus. 2012. Hubungan Keadilan Organisasional Dan Kecurangan pegawai Dengan Moderating Kualitas pengendalian Internal. The
Indonesian Accounting Review, Volume 2. No.2, pp. 159-172

Puspasari,Novita.,Suwardi,Eko.2012.Pengaruh Moralitas Individu Dan Pengendalian Internal Terhadap Kecenderungan Kecurangan Akuntansi: Studi Eksperimen Pada Konteks Pemerintahan Daerah. Simposium Nasional Akuntansi XV, Fakultas Ekonomi Universitas Lambung Mangkurat.

Rae, Kirsty., Subramaniam, Nava. 2008. Quality of internal control procedures: Antecedents and moderating effect on organisational justice and employee fraud. Manajerial Auditing Journal. Vol.23, No.2, pp. 104124

Robbins, Stephen. P., Judge, Timothy. A. 2009. Organizational Behavior (13rd ed). New Jersey : Pearson Education

Singleton, Tommie W., Singleton, Aaoron J. 2010. Fraud Auditing and Forensic Accounting. John Wiley

Suartana, I Wayan. (2010). Akuntansi Keperilakuan: Teori dan Implementasi. Yogyakarta: Penerbit ANDI

Wells, J. T. 2007. Corporate Fraud Handbook: Prevention and Detection: Second Edition. John Wiley and Sons Inc.

Wilopo. 2006. Analisis Faktor-Faktor yang Berpengaruh Terhadap Kecenderungan Kecurangan Akuntansi : Studi pada Perusahaan Publik dan Badan Usaha Milik Negara (BUMN) di Indonesia. Jurnal Riset Akuntansi Indonesia vol.9. 